\title{
Author Index Volume 11
}

Acheampong, G., Braimah, M., Quaye, D. M. and Buame, S. K., Impact of Demographic Factors on Technological Orientations of BOP Entrepreneurs in Ghana

$11(2014) 1450037$

Aggarwal, K. K. and Kumar, A., Economic Order Quantity Model with Innovation Diffusion Criterion under Influence of Price-Dependent Potential Market Size

$11(2014) 1450028$

Ahn, M. J., Enhancing Corporate Governance in High-Growth Entrepreneurial Firms

Al-Ansaari, Y., Pervan, S. and Xu, J., Exploiting Innovation in Dubai SMEs: The Effect of Strategic Orientation on Organizational Determinants

11 (2014) 1450038

$11(2014) 1450039$

Arman, H., Gindy, N., Kabli, M. and Cavin, S., Integrated Technology Roadmapping Tool to Aid the Decision-Making of RED Investments

Aronson, Z. H., Shenhar, A. J. and Wang, W., The Effect of Vision, Artifacts, and Leader Values on Contextual Performance Behavior and Success in Technology Challenging Projects: Qualitative Evidence

Ashill, N., see Haverila, M. J.

Balakrishnan, N., see Mathew, M.

Beşli, E. and Öner, M. A., An Exploratory Study on the Development and Application of Integrated Information Technology Management Model

Bouwman, H., de Reuver, M., Hampe, F., Carlsson, C. and Walden, P., Mobile RED Prototypes - What is Hampering Market Implementation?

Braimah, M., see Acheampong, G.

Brem, A., Gerhard, D. A. and Voigt, K.-I., Strategic Technological Sourcing Decisions in the Context of Timing and Market

Strategies: An Empirical Analysis

11 (2014) 1450006

Buame, S. K., see Acheampong, G.

Buijs, J., see Steen, M.

Carlsson, C., see Bouwman, $\mathrm{H}$.

Cavin, S., see Arman, H.

11 (2014) 1450040

11 (2014) 1450024

11 (2014) 1450005

$11(2014) 1450018$

11 (2014) 1440003

11 (2014) 1450037

11 (2014) 1450016

11 (2014) 1450037

11 (2014) 1440001

11 (2014) 1440003

11 (2014) 1450006 
Ceci, F. and D'Andrea, D., Knowledge Dynamics in Fragmented Industries

Chai, K.-H., see Chu, M.-T.

Chen, J., see Wang, F.

Chou, J. C.-L., see Hung, C.-L.

Chu, M.-T., Khosla, R. and Chai, K.-H., A Cluster Analysis of IC Design Industry

Cordeiro, P. V. M., Dergint, D. E. A. and Hatakeyama, K., Proposal of Method for an Automatic Complementarities Search between Companies' RED

Counsell, S., see Hameed, M. A.

D'Andrea, D., see Ceci, F.

Dasgupta, M., Unveiling Technology Acquisition and Deployment Decisions for Technological Innovation: An Exploratory Study in Indian Power Distribution Firms

de Reuver, M., see Bouwman, $\mathrm{H}$.

Deken, F. and Lauche, K., Coordinating Through the Development of a Shared Object: An Approach to Study Interorganizational Innovation

Dergint, D. E. A., see Cordeiro, P. V. M.

Dietrich, P., see Jepsen, L. B.

Do, T. H., Determinants of Innovation Commercialization Management and Anticipated Returns: An Exploratory Typology of SMEs

Durmusoglu, S. S., see Nayir, D. Z.

Elfström, B.-O., see Wallin, J.

Elyasi, M., see Mohammadi, M.

Eyo, S. J., Japan's Bioventures: Past, Present and Future

$\mathrm{Fu}$, X., see Wang, F.

Gerdsri, N., see Intarakumnerd, P.

Gerhard, D. A., see Brem, A.

Gindy, N., see Arman, H.

Gomes, P. J., Erratum - Framing Ambiguity During Product Development: A Knowledge-Involved Perspective

Gonzalez, W., Applying Agile Project Management to Predevelopment Stages of Innovation

Gudem, M., Steinert, M. and Welo, T., From Lean Product Development to Lean Innovation: Searching for a More Valid Approach for Promoting Utilitarian and Emotional Value

Gutiérrez, E., Managing Ambiguity When Evaluating and Selecting New Ideas in Project Portfolio Management

Hameed, M. A. and Counsell, S., User Acceptance Determinants of Information Technology Innovation in Organizations

Hampe, F., see Bouwman, H.

Haruechaiyasak, C., see Kongthon, A.

Hatakeyama, K., see Cordeiro, P. V. M.

11 (2014) 1450004

11 (2014) 1450003

11 (2014) 1450013

11 (2014) 1450010

11 (2014) 1450003

11 (2014) 1450001

11 (2014) 1450033

11 (2014) 1450004

11 (2014) 1450041

11 (2014) 1440003

11 (2014) 1440002

11 (2014) 1450001

11 (2014) 1450009

11 (2014) 1450042

11 (2014) 1450029

11 (2014) 1440005

11 (2014) 1450014

11 (2014) 1450031

11 (2014) 1450013

11 (2014) 1440009

11 (2014) 1450016

11 (2014) 1450006

11 (2014) 1492001

11 (2014) 1450020

11 (2014) 1450008

11 (2014) 1450030

11 (2014) 1450033

11 (2014) 1440003

11 (2014) 1440012

11 (2014) 1450001

Haverila, M. J. and Ashill, N., Launch Effort and NPD Success: A Study of Technology Intensive Companies in Finland

$11(2014) 1450024$ 
Hermeler, H., see van der Duin, P.

Ho, J. C., see Lee, C.-S.

Ho, L.-P., see Wu, S.-I.

Hung, C.-L. and Chou, J. C.-L., Examining the Cultural Moderation on the Acceptance of Mobile Commerce

Hüsig, S., A Typology for Radical Innovation Projects Based on an Innovativeness Framework

Intarakumnerd, P. and Gerdsri, N., Implications of Technology Management and Policy on the Development of a Sectoral Innovation System: Lessons Learned Through the Evolution of Thai Automotive Sector

Isaksson, O., see Wallin, J.

Jantunen, A., see Spodniak, P.

Jepsen, L. B. and Dietrich, P., Technology Uncertainty and Project Managers' Information Sharing - A Comparative Case Study of Two New Product Development Projects

Johansson, C., Managing Uncertainty and Ambiguity in Gates: Decision Making in Aerospace Product Development

Kabli, M., see Arman, H.

Kammoun, O. and Rahmouni, M., Appropriation Instruments and Innovation Activities: Evidence from Tunisian Firms

Kato, K. and Miyazaki, K., Application Path for Promoting Technology Commercialization

Khosla, R., see Chu, M.-T.

Kiasari, M. M., see Mohammadi, M.

Klein, G., Evaluation of Core and Symbolic Capabilities During Due-Diligence Processes in New Biotechnology Firms

Kleinsmann, M., see van der Duin, P.

Kongthon, A., Haruechaiyasak, C., Pailai, J. and Kongyoung, S., The Role of Social Media During a Natural Disaster: A Case Study of the 2011 Thai Flood

Kongyoung, S., see Kongthon, A.

Kouris, S., see Minshall, T.

Kumar, A., see Aggarwal, K. K.

Kumar, P. V., see Saripalle, R. S.

Larsson, A., see Wallin, J.

Lauche, K., see Deken, F.

Lee, C.-S. and Ho, J. C., National and Industrial Strategies for Value Creation in a Global Context

Magnier-Watanabe, R., see Mathew, M.

Malinen, P., see Pellikka, J. T.

Mathew, M., Magnier-Watanabe, R., Pratheeba, S. and

Balakrishnan, N., Assessing Technology Differences in Electronic and Mobile Payment Systems among Developed and Developing Countries

Maurer, C. and Valkenburg, R., Approaches to Networked Innovation
11 (2014) 1440008

11 (2014) 1440010

11 (2014) 1450026

11 (2014) 1450010

11 (2014) 1450023

11 (2014) 1440009

11 (2014) 1440005

11 (2014) 1450017

11 (2014) 1450009

11 (2014) 1450012

11 (2014) 1450006

11 (2014) 1450046

11 (2014) 1450025

11 (2014) 1450003

11 (2014) 1450014

11 (2014) 1450043

11 (2014) 1440007

11 (2014) 1440012

11 (2014) 1440012

11 (2014) 1440006

11 (2014) 1450028

11 (2014) 1450036

11 (2014) 1440005

11 (2014) 1440002

11 (2014) 1440010

11 (2014) 1450005

11 (2014) 1450007

11 (2014) 1450005

11 (2014) 1440004 
Minshall, T., Kouris, S., Mortara, L., Schmithausen, P. and

Weiss, D., Developing Infrastructure to Support Open Innovation:

Case Studies from the East of England

Miyazaki, K., see Kato, K.

Mohamadnejad, F., A DEMATEL-Based Framework for

Identification of Causalities among Internal and External Modes of Technology Acquisition

Mohammadi, M., Elyasi, M. and Kiasari, M. M., Developing a Model for Technological Capability Assessment - Case of Automotive Parts Manufacturers in Iran

Mortara, L., see Minshall, T.

Mousavinasab, S. M. H., see Nejadhussein, S.

Nayir, D. Z., Tamm, U. and Durmusoglu, S. S., How Formalization Hinders Different Firm Innovativeness Types: Opening the Black Box with Evidence from a Service Industry

Nejadhussein, S., Rahimian, M. A. H. and Mousavinasab, S. M. H., The Relationship between Knowledge Management and RED Performance: A Case Study in Auto Industry

Öner, M. A., see Beşli, E.

Pailai, J., see Kongthon, A.

Pattit, J. M., Raj, S. P. and Wilemon, D. L., The REDD Outsourcing Decision: Environmental Factors and Strategic Considerations

Pellikka, J. T. and Malinen, P., Business Models in the Commercialization Processes of Innovation among Small High-Technology Firms

Pervan, S., see Al-Ansaari, Y.

Platzek, B. P., Pretorius, L. and Winzker, D. H., The Vital Entrepreneurial Learning Organization: A Corporate Mindset for Entrepreneurial Change Management

Pratheeba, S., see Mathew, M.

Pretorius, L., see Platzek, B. P.

Quan, X. I., see Wan, H.-H.

Quaye, D. M., see Acheampong, G.

Rahimian, M. A. H., see Nejadhussein, S.

Rahmouni, M., see Kammoun, O.

Raj, S. P., see Pattit, J. M.

Rampersad, G., Perceptions of Creativity in University-Industry Partnerships: A Pedagogical Approach

Saripalle, R. S., Kumar, P. V. and Tatavarti, R., Individual Innovation Index $\left(I^{3}\right)$ : Assessment and Enhancement

Schaarschmidt, M. and von Kortzfleisch, H., Examining Investment Strategies of Venture Capitalists in Open Source Software

Schmithausen, P., see Minshall, T.

Shenhar, A. J., see Aronson, Z. H.

Songkajorn, Y. and Thawesaengskulthai, N., Medical Device Innovation Development Process

$11(2014) 1440006$

$11(2014) 1450025$

$11(2014) 1450015$

11 (2014) 1450014

11 (2014) 1440006

11 (2014) 1450034

11 (2014) 1450029

11 (2014) 1450034

11 (2014) 1450018

11 (2014) 1440012

11 (2014) 1450002

11 (2014) 1450007

11 (2014) 1450039

11 (2014) 1450044

11 (2014) 1450005

11 (2014) 1450044

11 (2014) 1450032

11 (2014) 1450037

11 (2014) 1450034

11 (2014) 1450046

11 (2014) 1450002

11 (2014) 1450045

11 (2014) 1450036

11 (2014) 1450019

11 (2014) 1440006

11 (2014) 1450040

11 (2014) 1450027

Spodniak, P., Jantunen, A. and Viljainen, S., Diffusion and Drivers of Smart Meters: The Case of Central and Eastern Europe

$11(2014) 1450017$ 
Steen, M., Buijs, J. and Williams, D., The Role of Scenarios and Demonstrators in Promoting Shared Understanding in Innovation Projects

Steinert, M., see Gudem, M.

Tamm, U., see Nayir, D. Z.

Tatavarti, R., see Saripalle, R. S.

Thawesaengskulthai, N., see Songkajorn, Y.

Valkenburg, R., see Maurer, C.

Valkenburg, R., see van der Duin, P.

van der Duin, P. and Hermeler, H., Innovating in a Government Context: An Evaluation of a Dutch Water Innovation Program Using the Cyclic Innovation Model

van der Duin, P., Kleinsmann, M. and Valkenburg, R., Exploring a Design-Driven Approach as Way to Enable Networked Innovation: Synthesis and Future Research

Viljainen, S., see Spodniak, P.

Voigt, K.-I., see Brem, A.

von Kortzfleisch, H., see Schaarschmidt, M.

Walden, P., see Bouwman, H.

Wallin, J., Isaksson, O., Larsson, A. and Elfström, B.-O., Bridging the Gap between University and Industry: Three Mechanisms for Innovation Efficiency

Wan, H.-H. and Quan, X. I., Toward a Framework of the Process of Open Innovation - Case of Acclarent in the Medical Device Industry

Wang, F., Fu, X. and Chen, J., Differential Forms of Technological Change and Catch-Up: Evidence from China

Wang, W., see Aronson, Z. H.

Weiss, D., see Minshall, T.

Welo, T., see Gudem, M.

Weng, C. S., Technology Management: The Perspective of Social Network

Wilemon, D. L., see Pattit, J. M.

Williams, D., see Steen, M.

Winzker, D. H., see Platzek, B. P.

$\mathrm{Wu}$, S.-I. and Ho, L.-P., The Influence of Perceived Innovation and Brand Awareness on Purchase Intention of Innovation Product - An Example of iPhone

$\mathrm{Xu}, \mathrm{J}$, see Al-Ansaari, $\mathrm{Y}$.

Zhao, Y., Interpreting Innovation Dynamics with Complexity Theory
11 (2014) 1440001

11 (2014) 1450008

11 (2014) 1450029

11 (2014) 1450036

11 (2014) 1450027

11 (2014) 1440004

11 (2014) 1440007

$11(2014) 1440008$

11 (2014) 1440007

11 (2014) 1450017

11 (2014) 1450016

11 (2014) 1450019

11 (2014) 1440003

11 (2014) 1440005

11 (2014) 1450032

11 (2014) 1450013

11 (2014) 1450040

11 (2014) 1440006

11 (2014) 1450008

11 (2014) 1440011

11 (2014) 1450002

11 (2014) 1440001

11 (2014) 1450044

11 (2014) 1450026

11 (2014) 1450039

11 (2014) 1450035 